Disclosure of Interests: Marlene Stephan: None declared, Koray Tascilar: None declared, Melanie Hagen: None declared, Judith Haschka: None declared, Michaela Reiser: None declared, Fabian Hartmann: None declared, Arnd Kleyer Grant/research support from: Lilly, Consultant for: Lilly, Speakers bureau: Abbvie, Axel Hueber Grant/research support from: Novartis, Pfizer, Consultant for: Lilly, Speakers bureau: Lilly, Novartis, Janssen, Abbvie, Bernhard Manger: None declared, Camille Figuereido: None declared, Jayme Cobra: None declared, Hans-Peter Tony Consultant for: Eli Lilly and Company, Speakers bureau: Eli Lilly and Company, Stephanie Finzel: None declared, Stefan Kleinert Grant/research support from: Novartis, Consultant for: Novartis, UCB, Chugai, Celgene, Medac, Roche, Abbvie, Speakers bureau: Novartis, UCB, Chugai, Celgene, Medac, Roche, Abbvie, Joerg Wendler: None declared, Florian Schuch Consultant for: Celgene, Lilly, UCB, Roche, Sanofi-Aventis, Abbvie, Novartis, Speakers bureau: Celgene, Lilly, UCB, Roche, Sanofi-Aventis, Abbvie, Monika Ronneberger: None declared, Martin Feuchtenberger: None declared, Martin Fleck: None declared, Karin Manger: None declared, Wolfgang Ochs: None declared, Matthias Schmitt-Haendle: None declared, Hanns-Martin Lorenz: None declared, Hubert Nuesslein: None declared, Rieke Alten Grant/research support from: Bristol-Myers Squibb, Speakers bureau: Bristol-Myers Squibb, Jörg Henes: None declared, Klaus Krueger: None declared, Georg Schett: None declared, Jürgen Rech Grant/research support from: Bristol-Myers Squibb and Celgene (greater than \$10,000), Consultant for: Bristol-Myers Squibb, Celgene, Chugai, GlaxoSmithKline, Janssen, Eli Lilly, Novartis, Roche, Sanofi Aventis, and UCB (in total more than \$10,000), Speakers bureau: Bristol-Myers Squibb, Celgene, Chugai, GlaxoSmithKline, Janssen, Eli Lilly, Novartis, Roche, Sanofi Aventis, and UCB (in total more than $\$ 10,000$ )

DOI: 10.1136/annrheumdis-2019-eular.3987

\section{THU0101 TORQUE TENO VIRAL LOAD FOR MONITORING OF BIOLOGICAL THERAPIES IN RHEUMATOID ARTHRITIS}

Paul Studenic $^{1}$, Gregor Bond ${ }^{2}$, Andreas Kerschbaumer $^{1}$, Manuel Becede ${ }^{1}$, Karel Pavelka ${ }^{3}$, Dmitry Karateev ${ }^{4}$, Jutta Stieger ${ }^{5}$, Rudolf Puchner ${ }^{6}$, Rudiger Muller ${ }^{7}$, Elisabeth Puchhammer-Stöckl ${ }^{8}$, Martina Durechova ${ }^{1}$, Michaela Loiskandl ${ }^{1}$, Thomas Perkmann ${ }^{9}$, Marta Olejárova ${ }^{10}$, Elena Luchikhina ${ }^{4}$ Carl-Walter Steiner ${ }^{1}$, Michael Bonelli ${ }^{1}$, Josef S. Smolen ${ }^{1}$, Daniel Aletaha ${ }^{1} .{ }^{1}$ Medical University of Vienna, Division of Rheumatology, Vienna, Austria; ${ }^{2}$ Medical University of Vienna, Division of Nephrology and Dialysis, Vienna, Austria; ${ }^{3}$ Charles University in Prague, Department of Experimental Rheumatology, 1st Faculty of Medicine, Institute of Rheumatology, Prague, Czech Republic; ${ }^{4}$ Moscow Regional Research and Clinical Institute (MONIKI), Department of Rheumatology, Moscow, Russian Federation; ${ }^{5}$ Hietzing Hospital, 2nd Department of Medicine, Vienna, Austria; ${ }^{6}$ Rheumatologist in private practice, Wels, Austria; ${ }^{7}$ Kantonsspital Aarau, Division of Rheumatology, Aarau, Switzerland; ${ }^{8}$ Medical University of Vienna, Center for Virology, Vienna, Austria; ${ }^{9}$ Medical University of Vienna, Department of Laboratory Medicine, Vienna, Austria; ${ }^{10}$ Charles University in Prague, Department of Experimental Rheumatology, 1st Faculty of Medicine, Institute of Rheumatology, Prague, Czech Republic

Background: The apathogenic and highly prevalent Torque Teno Virus (TTV) is associated with the immunocompetence of its host and has been proposed for immunologic monitoring in solid organ transplantation. Objectives: Herein we explore TTV levels in rheumatoid arthritis (RA) patients receiving biological disease-modifying anti-rheumatic drugs (bDMARDs) in the context of clinical response.

Methods: The BIOBIO study was designed to evaluate biomarkers for prediction of clinical response in patients with RA. Within this multicentre open-label trial, patients with insufficient response to MTX were randomized to TNFi (infliximab; INF), anti-IL-6 receptor (tocilizumab; TCZ), CTLA4-Ig (abatacept; ABA) or anti-CD20 (rituximab; RTX) in addition to MTX. TTV in peripheral blood samples was quantified at baseline and 3 months by RT-PCR.

Results: TTV was measured in 95 RA patients [INF $(n=23), \operatorname{TCZ}(n=22)$, ABA $(n=27)$ or RTX $(n=23)]$. Median TTV levels at baseline were $4.2 \times 10^{4}$ $\mathrm{c} / \mathrm{ml}$ with no difference between the treatment groups. After 3 months of treatment patients with INF $(p=0.018), \operatorname{ABA}(p=0.071)$ and RTX $(p \leq 0.001)$ showed an increase in TTV levels compared to baseline. There was no change in TTV in patients with TCZ, who were omitted from further analyses. TTV at 3 months after treatment was higher in patients achieving a SDAI85 response at month $6(\mathrm{p}=0.019)$. Levels of above $5.6 \times 10^{5} \mathrm{c} / \mathrm{ml}$ at month 3 showed a $67 \%$ specificity and $81 \%$ sensitivity for a SDAI85 response at month 6 , corresponding to a positive likelihood ratio of 2.6
(95\% Cl: 1.6-4.1). Patients in the top tertile of month 3 TTV $\left(>7.8 \times 10^{5}\right.$ $\mathrm{c} / \mathrm{ml}$ ) had lower SDAI, CDAI and DAS28 and higher SDAI85 response rates at month 6 (OR: 4.18, $\mathrm{Cl}: 1.41-16.42 ; \mathrm{p}=0.012)$. The highest non response rates were found in patients within the lowest TTV tertile (Table A), and the highest remission rates were found in the highest TTV tertile (Table B). No patient below a TTV value of $2.7 \times 10^{4} \mathrm{c} / \mathrm{ml}$ at month 3 showed SDAI85 treatment response at month 6 .

Conclusion: Our data suggest that TTV levels in patients with RA treated with INF, ABA or RTX at month 3 are associated with clinical responses at month 6, and thus may constitute a biomarker for therapeutic monitoring.

Abstract THU0101 -Table 1.

\begin{tabular}{|c|c|c|c|c|c|c|c|c|c|c|c|}
\hline A & $\begin{array}{c}\text { No } \\
\text { response }\end{array}$ & SDAI50 & SDA170 & SDAI85 & Total & B & HDA & MDA & LDA & REM & Total \\
\hline LTTV & $43.8 \%$ & $37.5 \%$ & $18.8 \%$ & $0.0 \%$ & $100 \%$ & LTTV & $25.0 \%$ & $31.3 \%$ & $43.8 \%$ & $0.0 \%$ & $100 \%$ \\
\hline MTTV & $15.8 \%$ & $42.1 \%$ & $26.3 \%$ & $15.8 \%$ & $100 \%$ & MTTV & $5.0 \%$ & $35.0 \%$ & $40.0 \%$ & $20.0 \%$ & $100 \%$ \\
\hline HTTV & $27.3 \%$ & $18.2 \%$ & $18.2 \%$ & $36.4 \%$ & $100 \%$ & HTTV & $17.4 \%$ & $26.1 \%$ & $21.7 \%$ & $34.8 \%$ & $100 \%$ \\
\hline
\end{tabular}

Cross-tables: A - Left: depicting distribution of patients in different SDAI response categories at 6 months (non-overlapping) by tertiles of TTV at 3 months (LTTV: low tertile; MTTV: middle tertile; HTTV: high tertile). B - Right: depicting distribution of patients in different disease activity states at 6 months (HDA=high disease activity; MDA=moderate disease activity; LDA=low disease activity; REM=remission) by tertiles of TTV at 3 months

Acknowledgement: This study was supported by a grant of the Austrian Science Funds (FWF, grant-ID: KLI072)

Disclosure of Interests: Paul Studenic: None declared, Gregor Bond: None declared, Andreas Kerschbaumer Speakers bureau: Bristol-Myers Squibb, Celgene, Pfizer, Manuel Becede: None declared, Karel Pavelka: None declared, Dmitry Karateev: None declared, Jutta Stieger: None declared, Rudolf Puchner: None declared, Rudiger Muller: None declared, Elisabeth Puchhammer-Stöckl: None declared, Martina Durechova: None declared, Michaela Loiskandl: None declared, Thomas Perkmann: None declared, Marta Olejárova: None declared, Elena Luchikhina: None declared, Carl-Walter Steiner: None declared, Michael Bonelli: None declared, Josef S. Smolen Grant/research support from: AbbVie, Eli Lilly, Janssen, MSD, Pfizer Inc, Roche, Consultant for: AbbVie, Amgen, AstraZeneca, Astro, Celgene, Celtrion, Eli Lilly, GlaxoSmithKline, ILTOO, Janssen, Medimmune, MSD, Novartis-Sandoz, Pfizer Inc, Roche, Samsung, Sanofi, UCB, Speakers bureau: AbbVie, Amgen, AstraZeneca, Astro, Celgene, Celtrion, Eli Lilly, GlaxoSmithKline, ILTOO, Janssen, Medimmune MSD, Novartis-Sandoz, Pfizer Inc, Roche, Samsung, Sanofi, UCB, Daniel Aletaha Grant/research support from: AbbVie, Bristol-Myers Squibb, and MSD, Consultant for: AbbVie, Bristol-Myers Squibb, Eli Lilly, Janssen, Medac, Merck, MSD, Pfizer Inc, Roche, and UCB, Speakers bureau: AbbVie, Bristol-Myers Squibb, Eli Lilly, Janssen, Medac, Merck, MSD, Pfizer Inc, Roche, and UCB DOI: 10.1136/annrheumdis-2019-eular.5080

\section{THU0102 PATIENT DISEASE TRAJECTORIES IN BARICITINIB- TREATED PATIENTS WITH RHEUMATOID ARTHRITIS AND INADEQUATE RESPONSE TO METHOTREXATE}

Peter C. Taylor $^{1}$, Paul Emery ${ }^{2}$, Michael E. Weinblatt ${ }^{3}$, Eduardo Mysler ${ }^{4}$, Andrea Rubbert-Roth ${ }^{5}$, Bochao $\mathrm{Jia}^{6}$, Luna Sun ${ }^{6}$, Yushi Liu ${ }^{6}$, Yun-Fei Chen ${ }^{6}$, Anabela Cardoso ${ }^{6}$, Yoshiya Tanaka ${ }^{7} .{ }^{1}$ University of Oxford, Oxford, United Kingdom; ${ }^{2}$ University of Leeds, Leeds, United Kingdom; ${ }^{3}$ Brigham and Women's Hospital, Boston, United States of America; ${ }^{4}$ Organización Médica de Investigación, Buenos Aires, Argentina; ${ }^{5}$ Kantonsspital St. Gallen, St. Gallen, Switzerland; ${ }^{6}$ Eli Lilly and Company, Indianapolis, United States of America; ${ }^{7}$ University of Occupational and Environmental Health, Kitakyushu, Japan

Background: In RA-BEAM phase 3 study, baricitinib (bari) $4 \mathrm{mg}$ demonstrated clinical efficacy in patients (pts) with rheumatoid arthritis (RA) and an inadequate response to methotrexate. Bari, a selective Janus kinase 1/ 2 inhibitor, is approved for the treatment of moderate to severe active RA in adults in $>50$ countries. For improved treatment strategy, it is important to understand whether the pt population is composed of distinct pt groups with differing treatment responses and associated baseline characteristics.

Objectives: To identify different treatment trajectories, based on CDAI improvement, in bari $4 \mathrm{mg}$ treated pts over 52 weeks; and examine the associated clinical disease measures, structural damage score and baseline characteristics.

Methods: Growth Mixed Model (GMM), a novel latent class mixed model, was used to classify the longitudinal disease patterns instead of 
predefining a clinical responder at a specific time point. GMM was applied to observed CDAl values for bari $4 \mathrm{mg}$ pts, continuously treated from 0-52 weeks or up to rescue, to cluster pts into subgroups based on their trajectory patterns. Following identification of the groups, baseline pt characteristics and disease measures were compared between groups. Results: Bari $4 \mathrm{mg}$ treated pts $(\mathrm{N}=487)$ were classified into 3 groups based on their CDAl trajectory patterns: Group 1 ( $n=344,71 \%)$, Group 2 $(n=56,11 \%)$, and Group $3(n=87,18 \%)$ (Figure). Group 1 had lower baseline CDAI (34, Table 1), achieved CDAl $\leq 10$ (low disease activity, LDA) rapidly and maintained LDA up to 52 weeks. Group 2 had higher CDAl at baseline (48, Table 1), responded quickly, and although pts took longer to attain LDA, they continued to show CDAl improvement. Group 3 had similar baseline CDAl values (48, Table 1) to Group 2 but higher baseline damage (mean total Sharp score [mTSS] of 50, versus 41 for Groups 1 and 2, Table 1). Most Group 3 pts did not achieve LDA but continued to show improvement over time. The majority of pts had no radiographic progression with the highest proportion in Group 1 (Table 2). The trajectories of average pain VAS, Health Assessment QuestionnaireDisability Index (HAQ-DI), tender joint count 28 , and swollen joint count 28 were consistent in the 3 groups.

Abstract THU0102 -Table 1. Baseline characteristics:

\begin{tabular}{lccc}
\hline & Group 1 & Group 2 & Group 3 \\
$\mathbf{N}=\mathbf{3 4 4}$ & $\mathbf{N = 5 6}$ & $\mathbf{N = 8 7}$ \\
\hline Age & $53.8(12.1)$ & $54.0(12.7)$ & $52.2(12.4)$ \\
Male, $\mathrm{n}(\%)$ & $74(21.5)$ & $16(28.6)$ & $22(25.3)$ \\
BMI $\left(\mathrm{kg} / \mathrm{m}^{2}\right)$ & $26.8(5.7)$ & $25.9(6.0)$ & $27.0(6.1)$ \\
CDAl & $33.8(10.0)$ & $48.5(10.0)$ & $48.0(10.4)$ \\
mTSS & $41.0(49.1)$ & $40.6(41.8)$ & $49.8(58.6)$ \\
Duration from RA diagnosis (years) & $8.4(8.0)$ & $8.4(9.3)$ & $9.8(10.2)$ \\
HAQ-DI & $1.48(0.68)$ & $1.75(0.64)$ & $1.80(0.60)$ \\
\hline
\end{tabular}

Data reported as mean (SD) unless indicated

Abstract THU0102 - Table 2. Response rates in patient groups, n (\%)

\begin{tabular}{lcccc}
\hline & & $\begin{array}{c}\text { Group 1 } \\
\mathbf{N}=\mathbf{3 4 4}\end{array}$ & $\begin{array}{c}\text { Group 2 } \\
\mathbf{N}=56\end{array}$ & $\begin{array}{c}\text { Group 3 } \\
\mathbf{N}=\mathbf{8 7}\end{array}$ \\
\hline CDAl $\leq 10$ & W24 & $214(66.3)$ & $28(57.1)$ & $2(3.5)$ \\
\hline W52 & $235(76.8)$ & $36(85.7)$ & $8(16.0)$ & \\
mTSS change from baseline $\leq 0.5$ & W24 & $285(90.8)$ & $42(85.7)$ & $51(83.6)$ \\
& W52 & $266(89.3)$ & $34(82.9)$ & $40(80.0)$ \\
\hline
\end{tabular}

\section{W=week}

Conclusion: Baseline severity is associated with different treatment trajectories. With bari treatment, majority of pts achieved LDA and had no structural progression. Pts with high baseline disease activity were associated with longer time to achieve LDA. Pts with higher baseline structural damage in addition to high disease activity were less likely to achieve LDA, but consistent with the other groups, had similar low rate of joint damage progression. Long-term maintenance and continued improvement in CDAl were observed with bari treatment.

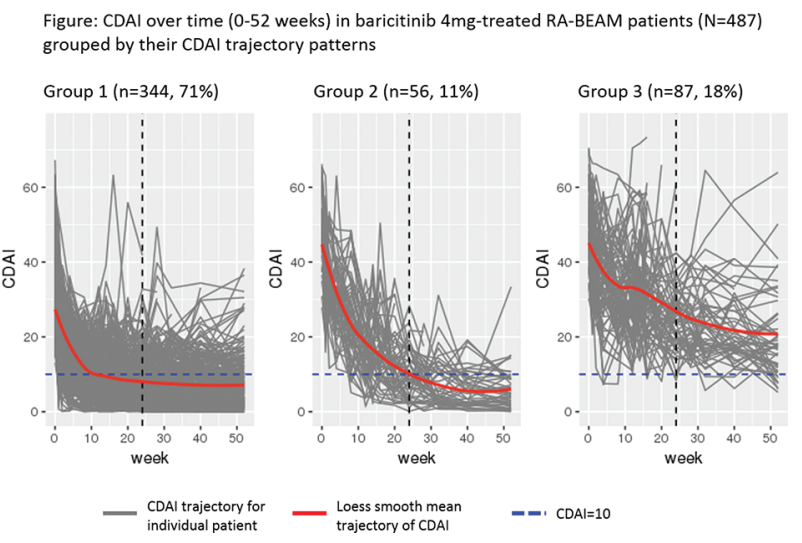

Abstract THU0102 - Figure 1
Disclosure of Interests: Peter C. Taylor Grant/research support from: Celgene, Galapagos, Eli Lilly, UCB, Consultant for: AbbVie, Galapagos, Gilead, Eli Lilly, Pfizer Inc, Paul Emery Grant/research support from: Pfizer, MSD, AbbVie, Bristol-Myers Squibb, Roche, Consultant for: Pfizer, MSD, AbbVie, Bristol-Myers Squibb, UCB, Roche, Novartis, Gilead,Samsung, Sandoz and Lilly, Michael E. Weinblatt Shareholder of: Stock option: CanFite, Lycera, Scipher, Inmedix, Grant/research support from: Crescendo Bioscience, Bristol Myers Squibb, Sanofi, Consultant for: AbbVie, Amgen, Bristol-Myers Squibb, CanFite, Corrona, Crescendo, GlaxoSmithKline, Gilead, Horizon, Lilly, Lycera, Merck, Novartis, Pfizer, Roche Samsung, Scipher, Set Point, Eduardo Mysler Grant/research support from: AbbVie, Bristol-Myers Squibb, Eli Lilly, Pfizer, Novartis, Janssen Grant/research support from: AbbVie, Bristol-Myers Squibb, Eli Lily, Jans sen, Medimmune, Pfizer Inc, and Roche, Consultant for: AbbVie, BristolMyers Squibb, Eli Lily, Janssen, Medimmune, Pfizer Inc, and Roche, Speakers bureau: AbbVie, Bristol-Myers Squibb, Eli Lilly, Pfizer, Novartis, Janssen, Speakers bureau: AbbVie, Bristol-Myers Squibb, Eli Lily, Janssen, Medimmune, Pfizer Inc, and Roche, Andrea Rubbert-Roth Consultant for: Chugai, Eli Lilly, Roche, and Sanofi, Speakers bureau: AbbVie, Bristol-Myers Squibb, Chugai, Hexal/Novartis, Janssen, Eli Lilly, Merck Sharp \& Dohme, Pfizer, Roche, and Sanofi, Bochao Jia Shareholder of: Eli Lilly and Company, Employee of: Eli Lilly and Company, Luna Sun Shareholder of: Eli Lilly and Company, Employee of: Eli Lilly and Company, Yushi Liu Shareholder of: Eli Lilly and Company, Employee of: Eli Lilly and Company, Yun-Fei Chen Shareholder of: Eli Lilly and Company Employee of: Eli Lilly and Company, Anabela Cardoso Shareholder of: Eli Lilly and Company, Employee of: Eli Lilly and Company, Yoshiya Tanaka Grant/research support from: Abbvie, Astellas, Bristol-Myers Squibb, Chugai, Daiichi-Sankyo, Eisai, Mitsubishi-Tanabe, MSD, Ono, Taisho-Toyama, Takeda, Speakers bureau: Abbvie, Asahi-kasei, Astellas, Bristol-Myers Squibb, Chugai, Daiichi-Sankyo, Eli Lilly, Eisai, Glaxo-Smithkline, Janssen, Mitsubishi-Tanabe, Novartis, Pfizer Japan Inc, Sanofi, Takeda, UCB, YL Biologics

DOI: 10.1136/annrheumdis-2019-eular.909

\section{THU0103 ONE IN FIVE PATIENTS WITH RAPIDLY AND PERSISTENTLY CONTROLLED EARLY RHEUMATOID ARTHRITIS REPORT POOR WELLBEING AFTER ONE YEAR OF TREATMENT}

Kristien Van der Elst ${ }^{1,2}$, Patrick Verschueren ${ }^{1,2}$, Diederik De Cock $^{2}$, An De Groef ${ }^{3,4}$, Veerle Stouten ${ }^{2}$, Sofia Pazmino ${ }^{2}$, Johanna Vriezekolk ${ }^{5}$, Johan Joly ${ }^{1}$, Philip Moons ${ }^{6,7}$, Rene Westhovens ${ }^{1,2}$. 1 University Hospitals Leuven, Rheumatology, Leuven, Belgium; ${ }^{2}$ KU Leuven - University of Leuven, Department of Development and Regeneration, Skeletal Biology and Engineering Research Center, Leuven, Belgium; ${ }^{3}$ KU Leuven - University of Leuven, Department of Rehabilitation Sciences, Leuven, Belgium; ${ }^{4}$ University Hospitals Leuven, Department of Physical Medicine and Rehabilitation, Leuven, Belgium; ${ }^{5}$ Sint Maartenskliniek, Rheumatology, Nijmegen, Netherlands; ${ }^{6} \mathrm{KU}$ Leuven - University of Leuven, Department of Public Health and Primary Care, Academic Center for Nursing and Midwifery, Leuven, Belgium; ${ }^{7}$ University of Gothenburg, Institute of Health and Care Sciences, Gothenburg, Sweden

Background: In rheumatoid arthritis (RA), good disease control without major joint damage, loss of function or disability can be achieved. Still, a substantial number of patients report poor wellbeing. A better understanding is needed on why some patients still feel unwell despite good disease control. Specific attention to this mismatch, especially early in the disease, could help to further optimize the clinical course of new patients with RA.

Objectives: To identify and characterize patients with early RA treated optimally to current standards but reporting not feeling well after 1 year of treatment.

Methods: We included participants of the Care in early RA trial with an early and persistently favorable treatment response, defined as having a disease activity score (DAS28CRP) $<2.6$ from 16 weeks after initiation of treatment until year 1. Feeling well was assessed with 5 patient-reported outcomes (PROs): pain, fatigue, physical functioning, RA-related quality of life and sleep quality. K-means clustering was carried out to assign patients to clusters based on these PRO scores at year 1. After clustering, Cohen's $d$ was computed to determine the magnitude of the difference between clusters, already at treatment start (BL) and 4 months 